\title{
Effects of nitrogen loading under low and high phosphorus conditions on above- and below-ground growth of hybrid larch $F_{1}$ seedlings
}

\author{
Saki Fujita ${ }^{(1)}$, \\ Xiaona Wang ${ }^{(2)}$, \\ Kazuhito Kita ${ }^{(3)}$, \\ Takayoshi Koike ${ }^{(4)}$
}

\begin{abstract}
Under present environmental conditions, hybrid larch $\mathrm{F}_{1}$ (Larix gmelinii var. japonica $\times$ Larix kaempferi) is a promising afforestation species as it has a high growth rate and tolerance against grazing damage, disease and cold. However, the input of nitrogen $(\mathrm{N})$ to forests due to the increase of anthropogenic $\mathrm{N}$ is causing imbalances of $\mathrm{N}$ compared to other nutrients, especially phosphorus $(P)$, thus affecting the root growth of healthy seedlings. However, knowledge on how different $\mathbf{N}$ and $\mathrm{P}$ conditions affect $\mathrm{F}_{1}$ root growth is still limited. In this study, various $\mathrm{N}$ ( 3 levels) and $\mathrm{P}$ (no addition and addition) conditions were imposed to investigate the effect of $\mathrm{N}$ loading on larch $\mathrm{F}_{1}$ seedlings under different $P$ conditions. Needle $N$ : $P$ ratio, aboveground growth, belowground growth as well as fine root production were measured. The results showed that needle N: P ratio was higher under low $\mathrm{P}$ loading, and aboveground growth of seedlings increased with $\mathrm{N}$ loading at both low and high $\mathrm{P}$ conditions. Relative fine root production was decreased by $\mathrm{N}$ loading. On the other hand, fine root to total dry proportion was increased by $\mathrm{N}$ loading at no $\mathrm{P}$ addition, suggesting that limited $\mathrm{P}$ availability could increase fine root production. Total root proportion to total dry mass was decreased by $\mathrm{N}$ loading at both $\mathrm{P}$ conditions. We concluded that $\mathrm{N}$ loading has different effects on above- and below-ground growth of larch $F_{1}$ and its effects may also differ according to $P$ conditions, indicating that both $\mathrm{N}$ and $\mathrm{P}$ conditions should be carefully considered when planting hybrid larch $F_{1}$.
\end{abstract}

Keywords: Nitrogen Deposition, Phosphorus, Fine Root Production, N: P Ratio, Hybrid Larch $F_{1}$

\section{Introduction}

The genus Larix is largely distributed over cool temperate regions in the northern hemisphere (Gower \& Richards 1990, Abaimov et al. 2002). Among the Larix species, Japanese larch (Larix kaempferi) is especially known for its high growth rate (Matyssek \& Schulze 1987) and is an important afforestation species across the northern hemisphere, especially in the east Eurasian regions (Ryu et al. 2009). However, problems such as low tolerance to vole feeding and shoot blight disease have raised concerns (Koike et al. 2000, 2004). To address these concerns, hybrid larch $\mathrm{F}_{1}$ was developed by intercrossing Dahurian larch (Larix gmelinii var. japonica) and Japa- nese larch. As a result, $F_{1}$ not only shows high tolerance to vole feeding and shoot blight disease but also has a higher initial growth rate and high capacity for carbon absorption under present environmental conditions such as $\mathrm{CO}_{2}$ concentration, temperature, rainfall etc. (Miyaki 1990, Kita et al. 2009, Ryu et al. 2009). As the Larix species is broadly distributed across east Eurasian regions (Abaimov et al. 2002), $F_{1}$ is one of the promising new afforestation species for $\mathrm{CO}_{2}$-fixation, storage and timber production. Therefore, it is important to investigate the $F_{1}$ 's growth under changing environmental conditions, such as the increase of nitrogen $(\mathrm{N})$ deposition which alters soil nutrient conditions.
(1) Graduate School of Agriculture, Hokkaido University, Sapporo 060-8589 (Japan); (2) Agricultural University of Hebei, Baoding 071-000 (China); (3) Forestry Research Institute, Hokkaido Research Organization, Bibai 079-0198 (Japan); (4) Research faculty of Agriculture, Hokkaido University, Sapporo 060-8589 (Japan)

@ Takayoshi Koike (tkoike@for.agr.hokudai.ac.jp)

Received: Feb 07, 2017 - Accepted: Nov 18, 2017

Citation: Fujita S, Wang X, Kita K, Koike T (2018). Effects of nitrogen loading under low and high phosphorus conditions on above- and below-ground growth of hybrid larch $F_{1}$ seedlings. iForest 11: 32-40. - doi: 10.3832/ifor2395-010 [online 2018-01-09]

Communicated by: Giustino Tonon
Anthropogenic $\mathrm{N}$ has been drastically increasing at global level since the industrial and agricultural revolution, and various studies have focused on its effects on forest ecosystems (Aber et al. 2003, Galloway et al. 2004, 2008, Matyssek et al. 2012). Since the growth of boreal forest ecosystems are reported to be limited by soil $\mathrm{N}$ (Vitousek et al. 2002), N input may increase plant growth to some extent. However, N saturation and negative effects have also been reported (Aber et al. 1989, Magill et al. 2004). Plant growth can also be limited by other elements such as phosphorus $(P)$. $P$ limitation has been observed in immature volcanic ash soil (Vitric Andisols), which show strong $P$ retention (Takahashi \& Shoji 2002). Therefore, increase of $\mathrm{N}$ deposition under Vitric Andisols may cause imbalances in soil $\mathrm{N}$ and $\mathrm{P}$, and simultaneously induce $\mathrm{P}$ limitation (Vitousek et al. 2010) which may potentially have negative effects on plant growth. The literature review by Peñuelas et al. (2013) reported that $\mathrm{N}$ deposition (or $\mathrm{N}$ loading) has indirect effects on plants by causing alteration to the $\mathrm{N}$ : $\mathrm{P}$ ratio. Several other studies have observed that $\mathrm{N}$ : $\mathrm{P}$ ratio of foliage correlates negatively with net photosynthetic rate (Reich \& Oleksyn 2004), plant growth (Elser et al. 2010) and biomass production (Güsewell 2004).

As $\mathrm{N}$ loading may be one approach to address N deposition effects, Qu et al. (2003) 
reported detrimental effects of $\mathrm{N}$ loading on root growth and biomass of larch $F_{1}$ seedlings by conventional and exponential fertilization methods. Indeed, high N loading decreased root length and surface, which resulted in decreased shoot development. Moreover, they noted that when enough $\mathrm{N}$ is available for seedlings, aboveground growth was prioritized over belowground growth. Mao et al. (2014) investigated the effect of $\mathrm{N}$ loading on 2-year-old $F_{1}$ seedlings at low soil $P$ conditions to evaluate $\mathrm{P}$ limitation induced by $\mathrm{N}$ increase. However, in contrast to their hypothesis, $\mathrm{N}$ loading had the same increasing effect on growth at both low and high $\mathrm{P}$ conditions in forest brown soil (Dystric Cambisols). Mao (2013) found that both N and P loading increased the surface area of fine roots in Vitric Andisols (low nutrient condition soil). As fine roots play the role of absorbing nutrients and water, fine root growth is vital for seedling survival and drought tolerance. Furthermore, fine roots are also strongly influenced by nutrient availability (Burton et al. 2000), and can be easily altered by changes in $\mathrm{N}$ and $\mathrm{P}$ conditions.

Previous studies on the effect of $\mathrm{N}$ loading on hybrid larch $F_{1}$ have focused on a single growing season (Koike et al. 2004, Watanabe et al. 2011, Mao 2013, Mao et al. 2014, Qu 2016). However, the effect of nutrient conditions may change according to loading duration, and the effect on belowground growth may also change. Therefore, there is a need to better understand how a longer loading duration affects the belowground growth of hybrid larch $F_{1}$.

Our objective was to investigate the effects of varying $N$ and $P$ conditions on above- and below-ground growth of hybrid larch $F_{1}$. We hypothesized that $N$ loading under low $\mathrm{P}$ conditions will increase $\mathrm{N}$ : $\mathrm{P}$ ratio, causing $\mathrm{P}$ limitation. Therefore, $\mathrm{N}$ loading will only have positive effects on growth under high $\mathrm{P}$ loading conditions. Also, root growth will decrease by $\mathrm{N}$ loading, and this will be more significant with $P$ loading, since aboveground growth will be prioritized instead of investments made for nutrient acquisition.

\section{Materials and methods}

\section{Plant material and soil conditions}

Thirty-six hybrid larch $F_{1}$ (Larix gmelinii var. japonica $\times$ Larix kaempferi) seedlings produced at the Hokkaido Forestry Research Institute (Bibai, Japan) were used. In 2012, the 2-year-old seedlings were taken out of a stock room and planted in $30 \mathrm{~L}$ pots filled with Akadama soil and Kanuma pumice soil at a volume ratio of 1: 1 . This soil mix was chosen to simulate Vitric Andosols, which are widely distributed across the Hokkaido Island. Both Akadama and Kanuana pumice soils are derived from volcanic soil and are high in aeration, water and fertilization retention, and water availability. These soils lack nutrients and absorb phosphoric acid, which make it diffi- cult for plants to absorb P. Akadama soil is slightly acidic $(\mathrm{pH}=5.2)$, whereas Kanuma pumice soil is acidic ( $\mathrm{pH}=4.8)$.

In spring 2015, seedlings were replanted into $44 \mathrm{~L}$ pots with the same soil mix to prevent their roots from becoming potbound (pot effect). Seedlings were grown at the experimental nursery of Hokkaido University $\left(43^{\circ} 07^{\prime} \mathrm{N}, 141^{\circ} 38^{\prime} \mathrm{E}\right.$, elevation 15 $m$ a.s.l.) under natural (open air) conditions. Annual average precipitation was $1274.5 \mathrm{~mm}$ and $1360.0 \mathrm{~mm}$ in 2015 and 2016, respectively, while annual average temperature was $10.0^{\circ} \mathrm{C}$ and $9.3^{\circ} \mathrm{C}$, respectively, as measured at the Sapporo Regional Headquarters (JMA: $43^{\circ} 03.6^{\prime} \mathrm{N}, 141^{\circ} 38^{\prime} \mathrm{E}$, elevation $19.7 \mathrm{~m}$ a.s.I.). When there was no rainfall for a week, seedlings were irrigated until the pots were fully watered. The snow free period is from mid-November to late April. The accumulated snow depth is approximately $1.2 \mathrm{~m}$ during mid-January to early March.

\section{Loading treatments}

To investigate the effects of $\mathrm{N}$ deposition at low and high $\mathrm{P}$ conditions, 3 levels of $\mathrm{N}$ and 2 levels of $P$ were imposed (Mao 2013, Mao et al. 2014). The loading treatment began in 2012 and continued until 2016 (4 years). The $3 \mathrm{~N}$ levels were: 0,50 and 100 $\mathrm{kg} \mathrm{N} \mathrm{ha-1} \mathrm{yr}^{-1}$ and were labeled as No, N50, $\mathrm{N} 100$, respectively. N50 treatment simulates the typical estimation of $\mathrm{N}$ deposition at Asian regions (Nakaji et al. 2001, Galloway et al. 2003) and the N100 treatment reflected an excessive $\mathrm{N}$ loading. Regarding $P$ loading, the high treatment was set at $50 \mathrm{~kg} \mathrm{P} \mathrm{ha}^{-1} \mathrm{yr}^{-1}$ (hereafter: P50) with reference to common agricultural practices, while $0 \mathrm{~kg} \mathrm{P} \mathrm{ha-1} \mathrm{yr}^{-1}$ was set as low $\mathrm{P}$ treatment (hereafter: Po). Six different treatments were obtained by combining the three $\mathrm{N}$ with the two $\mathrm{P}$ levels, which were labeled as follows: N100P50, N50P50, NoP50, N100Po, N50Po, and NoPo (control). There were 6 seedlings in each treatment for a total of 36 seedlings. Kanuma soil and Akadama soils have almost no nutrients, thus Hyponex ${ }^{\circledR}$ fertilizer (N: P: $\mathrm{K}=$ 6:10:5, Mg: 0.05\%, Mn: 0.001\%, B: 0.005\% HYPONex Japan, Japan) was added in 2015 as top dressing in mid-May and at the end of June with $1000 \times$ dilution by deionized water. By Hyponex addition, $12.5 \mathrm{~kg} \mathrm{~N}^{-1}$ $\mathrm{yr}^{-1}$ and $21.1 \mathrm{~kg} \mathrm{P}^{\mathrm{P}} \mathrm{ha}^{-1} \mathrm{yr}^{-1}$ was added. The amount added by Hyponex was subtracted from the $\mathrm{N}$ and $\mathrm{P}$ loading in 2015. However, since Hyponex was given to all seedlings, treatments No received $12.5 \mathrm{~kg} \mathrm{~N} \mathrm{ha}^{-1} \mathrm{yr}^{-1}$ and treatments Po received $21.1 \mathrm{~kg} \mathrm{P}^{\mathrm{P}} \mathrm{ha}^{-1}$ $\mathrm{yr}^{-1}$ in 2015.

Ammonium nitrate $\left(\mathrm{NH}_{4} \mathrm{NO}_{3}\right)$ was used as nitrogen source to simulate $\mathrm{N}$ deposition from acid rain and aerosols in Japan (Kaneyasu et al. 2014), while monopotassium phosphate $\left(\mathrm{KH}_{2} \mathrm{PO}_{4}\right)$ was used as $\mathrm{P}$ source. Both were dissolved and given with $500 \mathrm{~mL}$ of deionized water. In Hokkaido, a considerable amount of $\mathrm{N}$ is released from snowmelt, therefore $\mathrm{N}$ was ap- plied 3 times at a ratio of 2:1:1 (100 kg N ha-1 $\mathrm{yr}^{-1}$ : 50, 25, $25 \mathrm{~kg} \mathrm{~N} \mathrm{ha}^{-1} \mathrm{yr}^{-1}, 50 \mathrm{~kg} \mathrm{~N} \mathrm{ha}^{-1} \mathrm{yr}^{-1}$ : $25,12.5,12.5 \mathrm{~kg} \mathrm{~N} \mathrm{ha}^{-1} \mathrm{yr}^{-1}$ ) in mid-June, midJuly and mid-August. As for $\mathrm{P}$, it was applied 3 times at a ratio of 1:1:1 (16.7, 16.7, and $16.7 \mathrm{kgP} \mathrm{ha}^{-1} \mathrm{yr}^{-1}$ ) at the same time as $\mathrm{N}$. In 2016, $\mathrm{N}$ and $\mathrm{P}$ were applied in 4 times at a ratio of 2:1:1:1 for $\mathrm{N}\left(100 \mathrm{~kg} \mathrm{~N} \mathrm{ha}^{-1} \mathrm{yr}^{-1}: 40\right.$, 20, 20, $20 \mathrm{~kg} \mathrm{~N} \mathrm{ha}^{-1} \mathrm{yr}^{-1}, 50 \mathrm{~kg} \mathrm{~N}^{-1} \mathrm{yr}^{-1}: 20$, 10, 10, $10 \mathrm{~kg} \mathrm{~N} \mathrm{ha}^{-1} \mathrm{yr}^{-1}$ ) and a ratio of 1:1:1:1 for $\mathrm{P}\left(12.5,12.5,12.5,12.5 \mathrm{~kg} \mathrm{P} \mathrm{ha}^{-1} \mathrm{yr}^{-1}\right)$. This was to shorten the time between $\mathrm{N}$ and $\mathrm{P}$ applications and to prevent $\mathrm{N}$ and $\mathrm{P}$ from being washed away with rain as much as possible. Large plates were also placed under the pots to prevent leaching.

\section{Sampling and analysis}

\section{Aboveground}

To examine needle $\mathrm{N}$ and $\mathrm{P}$ concentration, a small proportion of needles located at the top part (i.e., elongation shoot and its branches) of all 36 seedlings were randomly collected before and after $\mathrm{N}$ and $\mathrm{P}$ loading treatments (2015: May 25 and September 3; 2016: June 12 and August 15). The sampled needles were dried at $70^{\circ} \mathrm{C}$ for 72 hours.

Leaf litter was also collected on December 15, 2015 and November 12, 2016 by covering each whole seedling with a litter trap made with $1 \mathrm{~mm}$ mesh net, as described in Miyaura \& Hozumi (1988). Traps were placed in mid-October of each year, right after the needles began to change color. The litter collected in 2015 was also used as total needle biomass. Collected leaves were dried at $70^{\circ} \mathrm{C}$ for 72 hours, and then weighed.

Needle $\mathrm{N}$ concentration was measured with a NC analyzer (Elemntar ${ }^{\oplus}$, VarioEL III, Germany), and the inductively coupled plasma-mass emission spectrometer ICPAES $^{\circledast}$ (IRIS/IRIS Advantage ICAP, Thermo Fisher Scientific Inc., MA, USA) was used to measure needle $\mathrm{P}$ concentration. Needle $\mathrm{N}$ : $P$ ratio was calculated by dividing needle $N$ concentration by needle $\mathrm{P}$ concentration (eqn. 1):

$$
N: P=\frac{N_{n}}{N_{p}}
$$

where $N_{n}$ and $N_{p}$ are the nitrogen and phosphorus concentration in needles, respectively.

Height $(\mathrm{cm})$ and stem basal diameter $(\mathrm{mm})$ of seedlings were measured 6 times from spring 2015 to autumn 2016 (April 8, 2015; June 2, 2015; September 30, 2015; November 20, 2015; May 13, 2016; August 31, 2015). Stem basal diameter was recorded as the average of two perpendicular measurements. The growth rate $(G R, \%)$ of height and stem basal diameter was calculated for each measurement interval (from time $t-1$ to $t$ ) as follows (eqn. 2):

$$
G R=\frac{M_{t}-M_{t-1}}{M_{t-1}} \cdot 100
$$


where $M_{t}$ and $M_{t-1}$ are the values measured at time $t$ and $t-1$, respectively.

The aboveground biomass was measured in September 2016 by harvesting the 4 tallest seedlings in each treatment. The selection of the four more robust seedlings from each treatment was done to avoid any bias related to possible mechanical injuries suffered by seedlings due to the heavy snowfall occurring in the experimental area (see above).

The aboveground biomass was separated into stem, branch and needle components. Each component was dried at $70{ }^{\circ} \mathrm{C}$ for 72 hours, and then weighed. The other 12 seedlings were not harvested until mid-November after collecting leaf fall.

\section{Belowground}

Fine roots were measured in 2015 by soil core samples (Mao 2013). Two soil cores from each pot were taken, and the fine roots inside the soil core were measured. Soil cores were approximately $30 \mathrm{~cm}$ deep and $3 \mathrm{~cm}$ in diameter (Daiki Co. Ltd, Tokyo, Japan), taken in symmetrical directions, approximately $10 \mathrm{~cm}$ away from the stem. The fine root sampling was done 5 times in 2015 (June 26, July 30, September 3, October 3 and November 14). Each soil sample was approximately $1 \%$ of the total pot volume. Circular plastic tubes were placed at the sampling locations in the pots, so that samplings could be carried out at the same place every time. The holes made after the sampling were refilled with similar conditioned soil. Using this procedure, the fine root biomass obtained from the soil cores reflected the fine root production between the sampling dates except the first sampling (June 26,2016 ). The soil cores were preserved at $4{ }^{\circ} \mathrm{C}$. The obtained fine roots were carefully washed with water and a brush. They were scanned with a scanner (CanoScan LiDE $200^{\oplus}$, Canon, Japan), dried at $70{ }^{\circ} \mathrm{C}$ for 72 hours, and then weighed. The root analyzation software WinRHIZO TRON $^{\circledast}$ 2012a (Regent Instruments Canada Inc., Canada) was used to measure root length $(\mathrm{cm})$. Specific root length $(\mathrm{SRL})$ was calculated for the total sampling core ac- cording to Ostonen et al. (2007).

Roots were harvested after the aboveground harvest in September 2016 (4 seedlings per treatment). Roots were divided into coarse $(>5 \mathrm{~mm})$ and fine roots $(<5$ $\mathrm{mm}$ ), dried at $70^{\circ} \mathrm{C}$ for 72 hours, and then weighed.

We calculated the relative fine root production ( $F R P, \mathrm{~g} \mathrm{~g}^{-1}$ ) from the total fine root production and the estimated total root biomass of 2015, as follows (eqn. 3):

$$
F R P=\frac{T(f r p)}{E(t r b)}
$$

where $T(f r p)$ is total fine root production of 2015 (initial sampling excluded), and $E(\operatorname{trb})$ is the estimated total root biomass of 2015. E(trb) was calculated from the relationships between stem basal diameter, aboveground biomass and belowground biomass (Fig. 1a, Fig. 1b) obtained from harvest measurement data of 2015 and 2016. Data of 2015 was obtained in spring 2015 from 19 additional seedlings ( $n=2-4$ for each treatment) which were subjected to the same $\mathrm{N}$ and $\mathrm{P}$ treatment, but were not included in the main experiment. The data of 2016 were obtained from the sampling material harvested in September (4 tallest seedlings in each treatment). To estimate total root biomass of NoPo (control), harvest data from 2015 was used. This was because the height for NoPo was significantly small and did not fit the regression line made with the data used in 2016. For the rest of the treatments, harvest data from 2016 were used.

\section{Statistics}

A fully randomized scheme with 3 levels of $\mathrm{N}\left(0,50,100 \mathrm{kgN} \mathrm{ha}^{-1}\right)$ and 2 levels of $\mathrm{P}$ was adopted in this study. Two-way ANOVA ( $n=36$, except litter: $n=12$ ) was used to evaluate the effect of $\mathrm{N}, \mathrm{P}$, and their interaction on aboveground growth, fine root production and nutrient condition. Biomass was evaluated using data from the 24 robust seedlings harvested in autumn 2016. All measurements were done once, except the measurement of stem basal diameter which was the average of 2 measurements. Regarding the litter, since there were only 12 seedlings in total (2 seedlings per treatment), we measured 2 samples per seedling for measurement robustness. All analysis was done using $R$ ver. 3.3.2, except the regression analysis, which was carried out using the software package Microsoft EXCEL $2013^{\oplus}$.

\section{Results}

\section{Aboveground}

Needle N, P concentration and needle $\mathrm{N}$ : $P$ ratio were measured to evaluate nutrient conditions of larch seedlings (Tab. 1). Both in 2015 and 2016, $\mathrm{N}$ loading increased the $\mathrm{N}$ concentration in needles for both $\mathrm{P}_{50} \mathrm{and}$ Po treatments. In 2016, needle $\mathrm{N}$ concentration was higher at Po treatment. In both 2015 and 2016, needle P concentration was higher in seedlings subjected to P50 treatment than under the Po treatment. In 2015, significant effects of $\mathrm{N}$ and $\mathrm{P}$ loading on needle $\mathrm{N}$ : $\mathrm{P}$ ratio were detected $(p=0.10)$, with values generally lower for seedlings grown under the P50 treatment. In 2016, only $\mathrm{P}$ had a significant effect and the needle $N$ : $P$ ratio was significantly higher for the Po seedlings. Litter $\mathrm{N}$ concentration was significantly lower than needle $\mathrm{N}$ concentration of growing season needles. However, in N10oPo, the litter N concentration was significantly higher compared to other treatments in both years (2015 and 2016).

$\mathrm{N}$ and $\mathrm{P}$ had similar effects on aboveground growth of seedlings (Fig. 2a, Fig. 2b, Tab. 2). Final height was increased by both $\mathrm{N}$ and $\mathrm{P}$ loading. Total height growth rate of 2015 was affected by both $\mathrm{N}$ and $\mathrm{P}$ loading, and $\mathrm{N}$ and $\mathrm{P}$ showed a significant interaction effect. Total growth rate of 2016 was overall smaller than that of 2015, and was significantly affected by $\mathrm{N}$ addition. Final stem basal diameter (SBD) was increased by both $\mathrm{N}$ and $\mathrm{P}$. Concerning SBD growth rate of 2015, $\mathrm{N}$ had an increasing effect. In 2016, N loading had a significant decreasing effect on all seedlings, except those of the NoPo treatment.

Tab. 1 - Mean value $( \pm S E)$ of each treatment on needle $\mathrm{N}$ concentration, needle $\mathrm{P}$ concentration, needle $\mathrm{N}$ : $\mathrm{P}$ ratio and litter $\mathrm{N}$ con centration ( $n=6$ for each treatment, litter $N$ concentration; $n=2,2$ measurements per seedling) of 2015 and 2015. No, N50 and N100 represent the different $\mathrm{N}$ loading treatments (No: $0 \mathrm{~kg} \mathrm{~N}^{-1} \mathrm{yr}^{-1}, \mathrm{~N} 50: 50 \mathrm{~kg} \mathrm{~N} \mathrm{ha}^{-1} \mathrm{yr}^{-1}$, N100: $100 \mathrm{~kg} \mathrm{~N}^{-1} \mathrm{yr}^{-1}$ ). Po indicates treat-

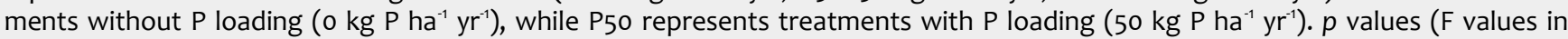
brackets) of two-way ANOVA are also shown. $(* * *): p<0.001 ;(* *): p<0.01 ;(*): p<0.05 ;$ (ns): not significant.

\begin{tabular}{|c|c|c|c|c|c|c|c|c|}
\hline \multirow{2}{*}{ Treatment } & \multicolumn{4}{|l|}{2015} & \multicolumn{4}{|l|}{2016} \\
\hline & Needle N & Needle P & Litter N & Needle N: P & Needle $\mathrm{N}$ & Needle P & Litter N & Needle N: P \\
\hline NOPO & $9.78 \pm 0.53$ & $0.67 \pm 0.02$ & $5.30 \pm 0.16$ & $14.73 \pm 0.78$ & $11.49 \pm 0.24$ & $0.36 \pm 0.09$ & $6.38 \pm 0.99$ & $43.32 \pm 13.32$ \\
\hline N0P50 & $7.54 \pm 0.31$ & $1.21 \pm 0.14$ & $4.48 \pm 0.19$ & $8.70 \pm 0.89$ & $9.46 \pm 0.40$ & $1.43 \pm 0.37$ & $2.38 \pm 1.60$ & $7.44 \pm 4.50$ \\
\hline N50P0 & $14.98 \pm 0.60$ & $1.05 \pm 0.05$ & $7.58 \pm 0.53$ & $15.65 \pm 1.18$ & $15.57 \pm 0.93$ & $0.30 \pm 0.04$ & $5.39 \pm 0.22$ & $60.12 \pm 10.74$ \\
\hline N50P50 & $16.24 \pm 0.57$ & $1.13 \pm 0.03$ & $5.60 \pm 0.18$ & $14.62 \pm 0.65$ & $13.64 \pm 0.33$ & $2.02 \pm 0.64$ & $3.44 \pm 2.43$ & $9.89 \pm 3.31$ \\
\hline N100P0 & $21.83 \pm 0.40$ & $0.94 \pm 0.03$ & $13.58 \pm 0.44$ & $24.48 \pm 1.24$ & $20.46 \pm 0.79$ & $0.48 \pm 0.07$ & $22.98 \pm 0.13$ & $41.50 \pm 5.54$ \\
\hline N100P50 & $20.93 \pm 0.39$ & $1.47 \pm 0.14$ & $5.90 \pm 0.19$ & $18.28 \pm 1.46$ & $16.75 \pm 0.22$ & $1.46 \pm 0.56$ & $4.49 \pm 0.98$ & $14.36 \pm 5.11$ \\
\hline $\mathrm{N}$ & *** $(58.77)$ & ns $(0.92)$ & $* * *(20.33)$ & $*(6.25)$ & ${ }^{* * *}(18.47)$ & ns $(0.20)$ & $* * *(138.03)$ & ns $(0.91)$ \\
\hline $\mathrm{P}$ & ns $(0.43)$ & ${ }^{*}(5.87)$ & $* * *(30.74)$ & ${ }^{*}(5.43)$ & * (4.94) & $* * *(26.24)$ & $* * *(231.31)$ & $* * *(34.70)$ \\
\hline$N \times P$ & ns $(1.13)$ & ns $(0.10)$ & $* * *(11.33)$ & ns (0.91) & ns $(0.30)$ & ns $(0.54)$ & $* * *(109.30)$ & ns $(0.82)$ \\
\hline
\end{tabular}


Fig. 1 - Regression relationship between: (a) stem basal diameter and aboveground biomass; and (b) aboveground biomass and total root biomass. The Regression equation, $\mathrm{R}^{2}$ and $p$ value from regression analysis are reported close to each line. The black lines represent the data from 2016 (harvest, $n=4$ for each treatment), and the gray lines represent data from 2015 ( $n=19,2-4$ seedlings for each treatment).
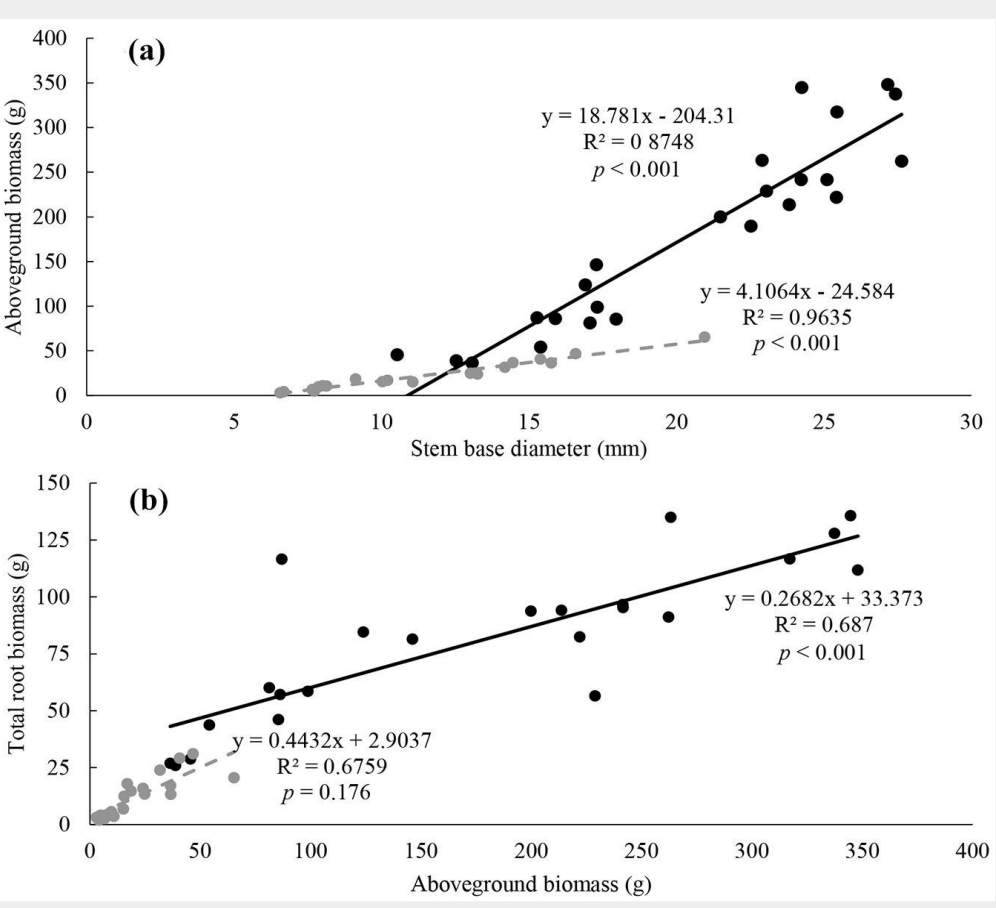

Fig. 2 - Height growth rate (a) and stem basal diameter growth rate (b) for 2 growing seasons from spring 2015 to autumn 2016 for each $\mathrm{N}$ and $\mathrm{P}$ treatment $(n=6$ for each treatment). No (dotted lines), N50 (dashed lines) and $\mathrm{N} 100$ (solid line) represent the different $\mathrm{N}$ loading treatments (No: $0 \mathrm{~kg} \mathrm{~N} \mathrm{ha}^{-1} \mathrm{yr}^{-1}, \mathrm{~N} 50: 50 \mathrm{~kg} \mathrm{~N}$

$\mathrm{ha}^{-1} \mathrm{yr}^{-1}$, N100: $\left.100 \mathrm{~kg} \mathrm{~N} \mathrm{ha}^{-1} \mathrm{yr}^{-1}\right)$. Po (gray) indicates treatments without $\mathrm{P}$ loading ( $\mathrm{o} \mathrm{kg} \mathrm{P} \mathrm{ha-1} \mathrm{yr}^{-1}$ ), while P50 (black) represents treatments with $P$ loading (50 $\left.\mathrm{kg} \mathrm{P} \mathrm{ha-1} \mathrm{yr}^{-1}\right)$. Measurement intervals are reportde on the horizontal axis. Bars represent the standard error.

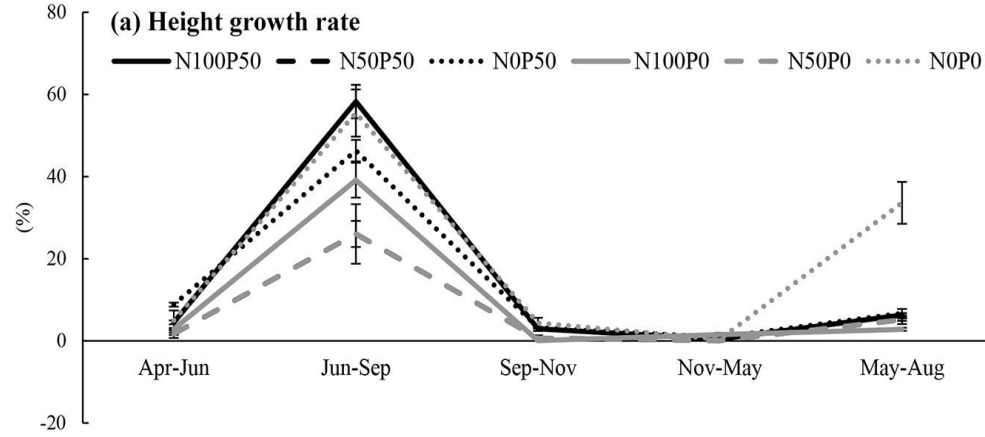

(b) Stem basal diameter growth rate

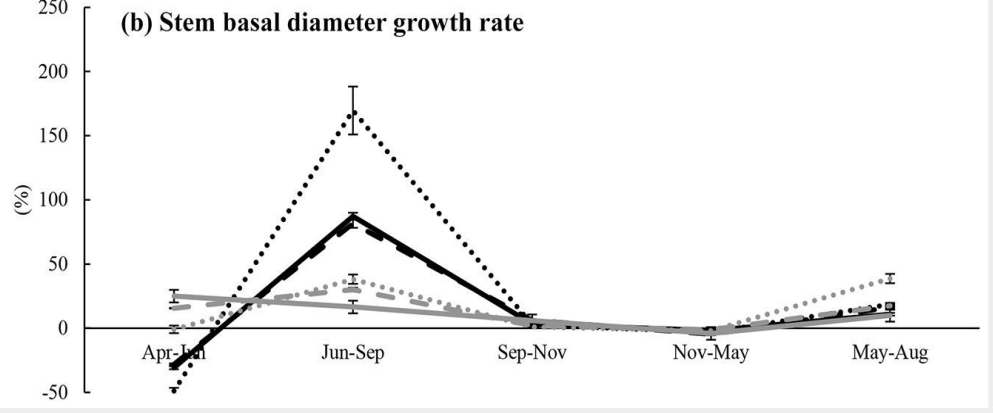

Tab. 2 - Mean value $( \pm S E)$ of each treatment on final height $(H)(\mathrm{cm})$, final stem basal diameter $(S B D)(\mathrm{mm})$, total height growth $(\mathrm{cm})$, height growth rate of $2015(\%)$, height growth rate of $2016(\%)$, total SBD growth $(\mathrm{mm})$, SBD growth rate of $2015(\%)$ and SBD growth rate of 2016 (\%). (No, N50, N100): different N loading treatments at 0,50 and $100 \mathrm{kgN} \mathrm{ha}^{-1} \mathrm{yr}^{-1}$, respectively. Po indicates treatments without $\mathrm{P}$ loading (o kg P ha $\left.{ }^{-1} \mathrm{yr}^{-1}\right)$, while $\mathrm{P} 50$ represent treatments with $\mathrm{P}$ loading $\left(50 \mathrm{~kg} \mathrm{P} \mathrm{ha}^{-1} \mathrm{yr}^{-1}\right)$. $p$ values $(F$ values in brackets) of two-way ANOVA are also shown. $(* * *): p<0.001 ;(* *): p<0.01 ;(*): p<0.05 ;(n s):$ not significant.

\begin{tabular}{|c|c|c|c|c|c|c|c|c|}
\hline Treatment & $\begin{array}{r}\text { Final } \\
(\mathrm{cm})\end{array}$ & $\begin{array}{l}\text { Final SBD } \\
(\mathrm{cm})\end{array}$ & $\begin{array}{c}\text { Total H } \\
\text { growth }(\mathrm{cm})\end{array}$ & $\begin{array}{c}2015 \mathrm{H} \\
\text { growth rate } \\
(\%)\end{array}$ & $\begin{array}{c}2016 \mathrm{H} \\
\text { growth rate } \\
(\%)\end{array}$ & $\begin{array}{l}\text { Total SBD } \\
\text { growth } \\
(\mathrm{mm})\end{array}$ & $\begin{array}{l}2015 \text { SBD } \\
\text { growth rate } \\
(\%)\end{array}$ & $\begin{array}{c}2016 \text { SBD } \\
\text { growth rate } \\
(\%)\end{array}$ \\
\hline NOPO & $55.37 \pm 4.18$ & $12.63 \pm 0.71$ & $29.98 \pm 1.71$ & $66.87 \pm 1.43$ & $33.66 \pm 1.71$ & $5.69 \pm 0.29$ & $36.76 \pm 4.03$ & $38.70 \pm 3.64$ \\
\hline NOP50 & $71.33 \pm 2.23$ & $25.55 \pm 0.84$ & $17.57 \pm 0.91$ & $22.34 \pm 1.17$ & $10.12 \pm 0.62$ & $4.92 \pm 0.24$ & $29.14 \pm 2.52$ & $18.47 \pm 1.28$ \\
\hline N50P0 & $98.18 \pm 9.24$ & $20.11 \pm 0.63$ & $40.92 \pm 3.77$ & $63.27 \pm 3.47$ & $6.74 \pm 0.53$ & $8.68 \pm 0.26$ & $52.61 \pm 1.43$ & $17.41 \pm 1.30$ \\
\hline N50P50 & $133.02 \pm 6.44$ & $23.44 \pm 1.23$ & $32.98 \pm 2.63$ & $29.20 \pm 2.60$ & $5.16 \pm 1.29$ & $7.93 \pm 0.50$ & $38.11 \pm 2.08$ & $16.11 \pm 1.69$ \\
\hline N100P0 & $140.00 \pm 7.26$ & $24.24 \pm 0.77$ & $44.35 \pm 2.81$ & $43.05 \pm 2.63$ & $2.82 \pm 0.55$ & $8.30 \pm 0.33$ & $44.81 \pm 1.72$ & $10.06 \pm 1.07$ \\
\hline N100P50 & $148.32 \pm 7.64$ & $15.78 \pm 0.59$ & $65.60 \pm 3.25$ & $67.87 \pm 2.95$ & $6.30 \pm 0.65$ & $7.86 \pm 0.32$ & $33.12 \pm 1.37$ & $10.86 \pm 1.04$ \\
\hline $\mathrm{N}$ & $* * *(64.78)$ & ${ }^{* * *}(88.35)$ & ${ }^{* * *}(11.32)$ & $* *(6.39)$ & $* *(6.57)$ & $* * *(8.01)$ & ns $(2.28)$ & $* *(7.81)$ \\
\hline $\mathrm{P}$ & $* *(10.70)$ & $* * *(15.59)$ & ns $(0.00)$ & $0.1(3.22)$ & ns $(0.99)$ & ns $(0.93)$ & * (5.64) & $0.1(3.03)$ \\
\hline$N \times P$ & ns (1.92) & ns $(0.79)$ & *(3.86) & ${ }^{*}(3.33)$ & ns (1.49) & ns $(0.02)$ & ns $(0.18)$ & $0.1(3.09)$ \\
\hline
\end{tabular}


Tab. 3 - Mean value $( \pm S E)$ of each treatment on stem, branch, needle, above, total, fine root, coarse, total root biomass ( $g$ ) from harvest in 2016 ( $n=4$ for each treatment). (No, N50, N100): different N loading treatments at 0,50 and $100 \mathrm{~kg} \mathrm{~N}^{-1} \mathrm{yr}^{-1}$, respectively. Po indicates treatments without $\mathrm{P}$ loading $\left(0 \mathrm{~kg} \mathrm{P} \mathrm{ha}^{-1} \mathrm{yr}^{-1}\right)$, while $\mathrm{P} 50$ represents treatments with $\mathrm{P}$ loading $\left(50 \mathrm{~kg} \mathrm{P}^{\mathrm{P}}\right.$ ha $\left.{ }^{-1} \mathrm{yr}^{-1}\right)$. $p$ values (F values in brackets) of two-way ANOVA are also shown. $(* * *): p<0.001 ;(* *): p<0.01 ;(*): p<0.05 ;$ (ns): not significant.

\begin{tabular}{|c|c|c|c|c|c|c|c|}
\hline Treatment & $\begin{array}{c}\text { Total } \\
\text { biomass }\end{array}$ & $\begin{array}{c}\text { Stem } \\
\text { biomass }\end{array}$ & $\begin{array}{c}\text { Branch } \\
\text { biomass }\end{array}$ & $\begin{array}{c}\text { Needle } \\
\text { biomass }\end{array}$ & $\begin{array}{c}\text { Fine root } \\
\text { biomass }\end{array}$ & $\begin{array}{c}\text { Coarse root } \\
\text { biomass }\end{array}$ & $\begin{array}{c}\text { Total root } \\
\text { biomass }\end{array}$ \\
\hline NOPO & $75.23 \pm 4.00$ & $12.93 \pm 0.76$ & $14.23 \pm 0.38$ & $16.58 \pm 2.34$ & $7.40 \pm 0.45$ & $24.10 \pm 1.66$ & $31.50 \pm 42.10$ \\
\hline N0P50 & $178.71 \pm 11.05$ & $39.68 \pm 4.90$ & $28.90 \pm 1.65$ & $31.58 \pm 2.71$ & $21.30 \pm 1.82$ & $57.25 \pm 5.55$ & $78.56 \pm 7.08$ \\
\hline N50P0 & $166.27 \pm 9.87$ & $39.20 \pm 3.24$ & $39.33 \pm 4.76$ & $45.80 \pm 7.41$ & $20.96 \pm 2.28$ & $42.70 \pm 2.74$ & $63.60 \pm 4.98$ \\
\hline N50P50 & $324.58 \pm 12.80$ & $93.40 \pm 2.31$ & $69.20 \pm 4.80$ & $69.30 \pm 4.87$ & $22.98 \pm 2.04$ & $69.70 \pm 6.35$ & $92.68 \pm 8.33$ \\
\hline N100P0 & $330.68 \pm 6.44$ & $92.28 \pm 2.63$ & $78.23 \pm 4.73$ & $65.78 \pm 1.80$ & $26.10 \pm 1.40$ & $68.30 \pm 1.69$ & $94.40 \pm 0.52$ \\
\hline N100P50 & $460.38 \pm 4.82$ & $111.73 \pm 1.17$ & $119.85 \pm 3.82$ & $105.25 \pm 5.41$ & $30.40 \pm 2.08$ & $93.15 \pm 3.80$ & $123.55 \pm 2.68$ \\
\hline $\mathrm{N}$ & *** $(118.79)$ & $* * *(88.28)$ & $* * *(53.11)$ & $* * *(91.64)$ & $* *(8.10)$ & $* * *(12.01)$ & $* * *(14.48)$ \\
\hline$P$ & *** (78.19) & ** $(51.71)$ & $* * *(21.73)$ & $* * * \quad(49.01)$ & $0.1(6.20)$ & $* * *(16.98)$ & *** (17.89) \\
\hline $\mathrm{N} \times \mathrm{P}$ & ns (1.14) & ${ }^{*}(5.17)$ & ns (1.60) & ${ }^{*}(3.74)$ & ns (1.91) & ns $(0.14)$ & ns $(0.57)$ \\
\hline
\end{tabular}

Tab. 4 - Mean value $( \pm S E)$ of each treatment on coarse root, fine root, total root, stem, branch, needle, and above total biomass proportion (\%). (No, N50, N100): different $\mathrm{N}$ loading treatments at 0,50 and $100 \mathrm{~kg} \mathrm{~N} \mathrm{ha}^{-1} \mathrm{yr}^{-1}$, respectively. Po indicates treatments without $\mathrm{P}$ loading ( $0 \mathrm{~kg} \mathrm{P} \mathrm{ha}^{-1} \mathrm{yr}^{-1}$ ) and $\mathrm{P}_{50}$ represents treatments with $\mathrm{P}$ loading ( $\left.50 \mathrm{~kg} \mathrm{P} \mathrm{ha}^{-1} \mathrm{yr}^{-1}\right) . p$ values ( $\mathrm{F}$ values in brackets) of two-way ANOVA are also shown. $(* * *): p<0.001 ;(* *): p<0.01 ;(*): p<0.05 ;$ (ns): not significant.

\begin{tabular}{|c|c|c|c|c|c|c|}
\hline Treatment & $\begin{array}{c}\text { Stem } \\
(\%)\end{array}$ & $\begin{array}{c}\text { Branch } \\
(\%)\end{array}$ & $\begin{array}{c}\text { Needle } \\
(\%)\end{array}$ & $\begin{array}{c}\text { Fine root } \\
(\%)\end{array}$ & $\begin{array}{c}\text { Coarse root } \\
\text { (\%) }\end{array}$ & $\begin{array}{c}\text { Total root } \\
\text { (\%) }\end{array}$ \\
\hline NOPO & $17.29 \pm 0.76$ & $19.22 \pm 0.55$ & $21.88 \pm 1.57$ & $9.81 \pm 0.14$ & $31.80 \pm 0.56$ & $41.61 \pm 0.67$ \\
\hline N0P50 & $21.73 \pm 1.57$ & $16.57 \pm 0.92$ & $18.00 \pm 1.03$ & $11.74 \pm 0.41$ & $31.96 \pm 2.13$ & $43.70 \pm 2.39$ \\
\hline N50P0 & $20.23 \pm 0.84$ & $18.24 \pm 0.36$ & $23.73 \pm 0.89$ & $12.20 \pm 0.79$ & $25.60 \pm 0.30$ & $37.80 \pm 0.95$ \\
\hline N50P50 & $29.30 \pm 1.30$ & $21.28 \pm 1.18$ & $21.44 \pm 0.92$ & $6.94 \pm 0.36$ & $21.03 \pm 1.21$ & $27.97 \pm 1.53$ \\
\hline N100P0 & $27.91 \pm 0.60$ & $23.47 \pm 1.03$ & $19.93 \pm 0.47$ & $7.97 \pm 0.52$ & $20.72 \pm 0.54$ & $28.69 \pm 0.63$ \\
\hline N100P50 & $24.29 \pm 0.28$ & $26.06 \pm 0.84$ & $22.83 \pm 0.83$ & $6.59 \pm 0.43$ & $20.23 \pm 0.79$ & $26.82 \pm 0.42$ \\
\hline $\mathrm{N}$ & $* *(6.54)$ & ** $(8.08)$ & $0.1(2.97)$ & ** $(9.35)$ & ${ }^{* * *}(13.77)$ & $* * *(17.40)$ \\
\hline $\mathrm{P}$ & $0.1(3.36)$ & ns $(0.38)$ & ns (1.45) & $0.1(3.25)$ & $\mathrm{ns}(0.61)$ & ns (1.77) \\
\hline$N \times P$ & * $(5.03)$ & ns (1.58) & * (5.99) & ${ }^{* *}(9.48)$ & ns $(0.58)$ & $0.1(2.52)$ \\
\hline
\end{tabular}

Total biomass, stem biomass, branch biomass and needle biomass of seedlings showed a significant increase after $\mathrm{N}$ and $\mathrm{P}$ loading (Tab. 3). Also, a significant interaction between $\mathrm{P}$ and $\mathrm{N}$ addition was detected on leaf and stem biomass.

$\mathrm{N}$ and $\mathrm{P}$ had different effects on proportion of stem, branch and needle biomass to total dry biomass (Tab. 4). Stem proportion was increased by $\mathrm{N}$ loading. An interaction effect was also observed. The proportion of branch and needle biomass over the total seedling biomass was increased only by $\mathrm{N}$ loading.

\section{Belowground}

Treatments with $\mathrm{N}$ and $\mathrm{P}$ loading showed larger fine root biomass values from core samples compared to treatments with no $\mathrm{N}$ or $\mathrm{P}$ (Fig. 3). This is because seedling size differed according to the different $\mathrm{N}$ and $\mathrm{P}$ conditions, and so the initial sampling results from core sampling also differed. Similar results were observed throughout the season. There was a severe decrease of fine root in between the first and the second core sampling, likely due to the fact that all fine roots at sampling points in the pots were removed with the first sampling. However, at the next sampling dates fine root production showed a slight trend with two peaks, one in later summer and another in late autumn (Fig. 3), though large differences existed among different treatments.
As shown in Fig. 4a and Tab. 5, N loading however, $\mathrm{N}$ loading did not show any sigdecreased relative fine root production nificant effect on the above ratio at Po and this was especially observed at Po. SRL treatments.

was not affected by neither $\mathrm{N}$ nor $\mathrm{P}$ load- Both fine and coarse root biomass of ing (Fig. 4b, Tab. 5). Seedlings subjected to seedlings were increased by both $\mathrm{N}$ and $\mathrm{P}$ $\mathrm{N}$ loading showed an increased needle: fine loading (Tab. 3). Furthermore, there were root biomass ratio in the $\mathrm{P}_{50}$ treatments; no significant effects of $\mathrm{N}$ and $\mathrm{P}$ loading on

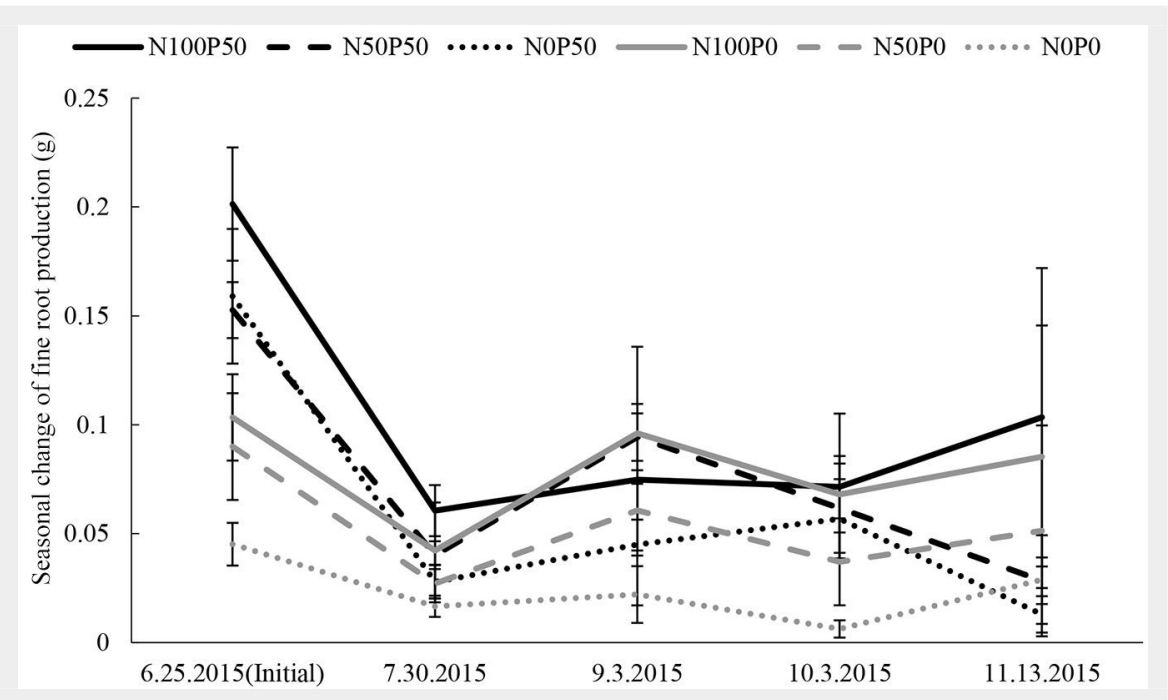

Fig. 3 - Seasonal change of fine root production, including the initial value (sampled on 6.25.2015). No (dotted lines), $N_{50}$ (dashed lines) and $N_{100}$ (solid line) represent the different $\mathrm{N}$ loading treatments (No: $0 \mathrm{~kg} \mathrm{~N} \mathrm{ha}^{-1} \mathrm{yr}^{-1}, \mathrm{~N} 50: 50 \mathrm{~kg} \mathrm{~N} \mathrm{ha}^{-1} \mathrm{yr}^{-1}, \mathrm{N100:} 100$ $\left.\mathrm{kg} \mathrm{N} \mathrm{ha}^{-1} \mathrm{yr}^{-1}\right)$. Po (gray) represents treatments without $\mathrm{P}$ loading (o kg P ha-1 $\mathrm{yr}^{-1}$ ) and P50 (black) represents treatments with $P$ loading (50 kg $P$ ha $\left.^{-1} \mathrm{yr}^{-1}\right)$. Measurement dates are reported on the horizontal axis. Bars are standard error. 

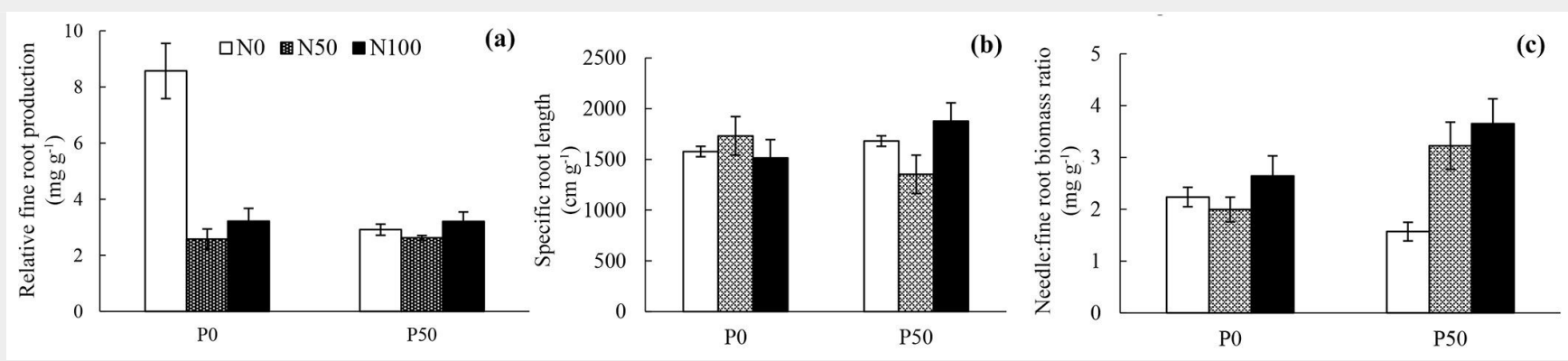

Fig. 4 - (a) Mean value of relative fine root production ( $\left.\mathrm{mg} \mathrm{g}^{-1}\right)$; (b) mean value of specific root length ( $\left.\mathrm{cm} \mathrm{g}^{-1}\right)$; (c) needle: total root biomass ratio $\left(\mathrm{g} \mathrm{g}^{-1}\right) \cdot n=6$ for each treatment in (a) and (b), while in (c) $n=4$ for each treatment. White bars represent No treatments (o kg N ha $\left.\mathrm{yr}^{-1}\right)$, meshed bars are N50 treatments ( $50 \mathrm{~kg} \mathrm{~N} \mathrm{ha}^{-1} \mathrm{yr}^{-1}$ ), and black bars N100 treatments (100 kgN ha $\left.{ }^{-1} \mathrm{yr}^{-1}\right)$. Whiskers represent the standard error.

fine: coarse root biomass ratio. However, fine root proportion was decreased by $\mathrm{N}$ loading (Tab. 4). On the other hand, it was slightly increased by $\mathrm{P}$ loading and an interaction effect was observed. Coarse root proportion was only significantly decreased by $\mathrm{N}$ loading, and total root proportion was significantly decreased by $\mathrm{N}$ and an interaction effect was observed.

As roots absorb nutrients from soil and needles absorb light for photosynthesis, their growth balance plays an important role in overall plant growth. Therefore, the needle biomass: fine root biomass ratio (Fig. 4c, Tab. 5) was calculated. As a result, needle biomass: fine root biomass was only increased in seedlings subjected to $\mathrm{N}$ loading under high P conditions. However, $\mathrm{N}$ loading did not show any significant effect at Po treatments.

\section{Discussion}

\section{Aboveground}

In both 2015 and 2016, N loading significantly increased needle $\mathrm{N}$ concentration. High needle $\mathrm{N}$ concentration commonly occurs with N loading (Ryan et al. 1996), and this was also observed in our study. Needle $P$ concentration was significantly higher at $P 50$ treatments, showing that $P$ addition increased needle $P$ concentration. However, the needle $P$ concentration of 2016 was smaller compared to 2015. The reason for this may be that Hyponex was added in 2015 as top dressing but not in 2016. Therefore, seedlings may have been experiencing higher $\mathrm{P}$ conditions and absorbed more $\mathrm{P}$ in 2015 compared to 2016, especially at Po treatments.

In 2015, both $\mathrm{N}$ and $\mathrm{P}$ loading had signifi- cant effects on $\mathrm{N}$ : $\mathrm{P}$ ratio. Here, $\mathrm{N}$ loading increased needle $\mathrm{N}$ : $\mathrm{P}$ ratio and treatments at $\mathrm{Po}$ had higher needle $\mathrm{N}$ : $\mathrm{P}$ ratio values. For most plants, $\mathrm{N}$ : $\mathrm{P}$ ratios $<10$ and $>20$ often correspond to $\mathrm{N}$ and $\mathrm{P}$ limited biomass production. Moreover, $10<\mathrm{N}$ : $\mathrm{P}<20$ often implies co-limitation (Güsewell 2004). Indeed, N100P50, N50P50, N50Po, and NoPo showed co-limitation in 2015, NoP50 showed $\mathrm{N}$ limitation and N100Po showed P limitation. In 2016, NoP50 and $\mathrm{N} 50 \mathrm{Po}$ showed $\mathrm{N}$ limitation, and N100P50 showed co-limitation. Hence, all treatments under low $\mathrm{P}$ condition showed $\mathrm{P}$ limitation. In 2016, only $P$ had significant effects on needle $N$ : $P$ ratio, and $N$ : $P$ ratio values were significantly higher at the Po treatment. However, since plant growth was not suppressed, $10<\mathrm{N}$ : $\mathrm{P}<20$ may not only indicate a co-limitation but also include favorable growth conditions for $F_{1}$ seedlings. Therefore, it may be difficult to determine co-limitation from $\mathrm{N}$ : $\mathrm{P}$ ratio and further investigations may be necessary.

Since $F_{1}$ is a deciduous conifer, nutrients such as $\mathrm{N}$ are retranslocated before leaf shedding (Chapin \& Kedrowski 1983, Wei et al. 2014). Retranslocation of $\mathrm{N}$ was also observed in our experiment, as litter $\mathrm{N}$ concentration was significantly lower than needle $\mathrm{N}$ concentration of needles sampled during the growing season. However, high litter $\mathrm{N}$ concentration was observed at only N100Po in both 2015 and 2016. Previous reports indicated that excessive $\mathrm{N}$ loading leads to high litter $\mathrm{N}$ concentration (Aber et al. 1989, Uddling et al. 2006, Watanabe et al. 2011, Dong-Gyu et al. 2015). The characteristic of N100Po is that it is $P$ limited and has a high needle $\mathrm{N}$ : $\mathrm{P}$ ratio. Therefore, these two factors are most

Tab. 5 - The statistical results of relative fine root production, specific root length and needle: fine root biomass ratio. $p$ values ( $F$ values) of two-way ANOVA are shown. $(* * *): p<0.001 ;(* *): p<0.01 ;(*): p<0.05 ;(n s)$ : not significant.

\begin{tabular}{lccc}
\hline Factors & $\begin{array}{c}\text { Relative fine root } \\
\text { production }\end{array}$ & $\begin{array}{c}\text { Specific root } \\
\text { length }\end{array}$ & $\begin{array}{c}\text { Needle: fine root } \\
\text { biomass ratio }\end{array}$ \\
\hline $\mathrm{N}$ & ${ }^{*}(3.80)$ & $\mathrm{ns}(0.27)$ & ${ }^{* *}(6.52)$ \\
$\mathrm{P}$ & $0.1(3.60)$ & $\mathrm{ns}(0.03)$ & $\mathrm{ns}(2.83)$ \\
$\mathrm{N} \times \mathrm{P}$ & ${ }^{*}(3.65)$ & $\mathrm{ns}(1.66)$ & ${ }^{*}(4.32)$ \\
\hline
\end{tabular}

likely causing high litter $\mathrm{N}$ concentration. It could be hypothesized that when $F_{1}$ seedlings lack $\mathrm{P}$ or have a high needle $\mathrm{N}$ : $\mathrm{P}$ ratio, the retranslocation of $\mathrm{N}$ from needle to other organs is suppressed, which leads to high litter $\mathrm{N}$ concentration. This could indirectly increase $\mathrm{N}$ input via litter, accelerating the soil $\mathrm{N}$ even more and change the chemistry and decomposition of the humus (Van Diepen et al. 2015). An interesting point is that although litter $\mathrm{N}$ was high in 2015, needle $\mathrm{N}$ concentration was also high for the next season (2016), indicating that N10oPo could absorb $\mathrm{N}$ again in the next growing season. It can also be hypothesized that seedlings of N100Po may not have retranslocated $\mathrm{N}$ to reduce the amount of $\mathrm{N}$ storage as to decrease needle $\mathrm{N}$ : $\mathrm{P}$ ratio.

$\mathrm{N}$ and $\mathrm{P}$ loading had positive effects on aboveground biomass. Therefore, $\mathrm{P}$ may have not been the critical limiting factor for aboveground growth; rather, $\mathrm{N}$ was the limiting factor. Li et al. (2016) compared the effect of $\mathrm{N}$ and $\mathrm{P}$ loading on two larch species (Larix kaempferi and L. olgensis). They found that $\mathrm{N}$ and $\mathrm{P}$ loading increased the productivity of both species; however, $P$ loading suppressed L. kaempferi productivity but increased L. olgensis. Therefore, for $L$. kaempferi $\mathrm{N}$ loading did not induce $\mathrm{P}$ deficiency; rather, $\mathrm{P}$ loading induced $\mathrm{N}$ limitation, which could indicate that in the latter species the demand for $\mathrm{N}$ is much higher than that for $P$. Since $F_{1}$ is a hybrid of L. kaempferi similar characteristics of $\mathrm{N}$ and $P$ demand may have been inherited (Szmidt et al. 1987, Wang et al. 2017).

A significant interaction effect of $\mathrm{N}$ and $\mathrm{P}$ loading on leaf and stem biomass was observed in this study, where $\mathrm{P}$ loading had a significantly higher increasing effect on seedlings subjected to $\mathrm{N} 50$ and $\mathrm{N} 100$ treatments. Based on the above evidence, it can be hypothesized that when nutrient availability is high, seedling investments in stem growth (height) and photosynthesis (needle) are prioritized.

Although seedlings were replanted in larger pots to prevent root growth inhibition (pot effect), possibilities of growth restriction can also be considered at the following treatments: N100P50, N50P50, 
N100Po and N50Po, since negative effects of $\mathrm{N}$ loading on height and stem basal diameter growth rates were observed in 2016 (Fig. 2a, Fig. 2b). Nutrient limitations may have also simultaneously occurred where the nutrient content in 2016 was not enough to support seedling growth after transplantation in 2015. Furthermore, as loading treatment was applied for as much as four years, continuous loading may have altered plants nutrient demand in $\mathrm{N}$ and $\mathrm{P}$ (Braun et al. 2010). Needle P concentration was also lower in 2016 and so $\mathrm{N}$ loading may have caused $P$ deficiency, and consequently, shortage of $\mathrm{P}$ may have decreased aboveground growth in 2016 compared to 2015.

Our results showed that $\mathrm{N}$ loading tends to increase the aboveground proportion of the total seedling biomass, especially at $\mathrm{P} 50$. It can be assumed that when $\mathrm{N}$ availability is high, seedlings have enough nutrients to support aboveground plant activities such as photosynthesis and so investments to the aboveground is prioritized instead of belowground. If this is so, $\mathrm{N}$ loading may induce imbalances between above- and below-ground growth.

\section{Belowground}

Regarding the seasonal changes of fine root production obtained from soil core samplings, a slight trend of two growing peaks was observed. This result was also observed by Satoh (1995), although the latter growing peak was relatively later in the autumn. This was especially seen in high $\mathrm{N}$ loading treatments. Therefore, the favorable nutrient condition of $\mathrm{N}$ and $\mathrm{P}$ may have prolonged the growing season of fine roots.

$\mathrm{N}$ loading decreased relative fine root production of seedlings under the Po treatments. Our starting hypothesis was that at P50 fine root production would decrease more than in the Po treatments. In our experiment, treatments other than NoPo had relatively low relative fine root production values. Therefore, $\mathrm{P}$ may have not been the limiting factor for fine root production and $\mathrm{N}$ was the determining factor in 2015. Fine root production may have been enhanced by seedlings grown at NoPo (low nutrient conditions) to absorb more nutrients. Both $\mathrm{N}$ and $\mathrm{P}$ loading did not affect SRL in our experiment. On the other hand, $\mathrm{N}$ loading increased total root biomass, including both coarse roots and fine roots at both $P$ conditions. This biomass increasing effect of $\mathrm{N}$ loading is consistent with other research results (Nadelhoffer 2000, Tingey et al. 2000). It can be hypothesized that seedlings were not experiencing $P$ deficiency and root growth was promoted to support aboveground growth.

We found that seedlings with high needle $\mathrm{N}$ : $\mathrm{P}$ ratio allocated less biomass to roots compared to seedlings with low needle $\mathrm{N}$ : $\mathrm{P}$ ratio (Tab. 4). This trend has also been reported by previous research (Güsewell 2004). Similarly, total root proportion was significantly higher at NoPo than at N100Po treatment, and NoP50 was higher than $\mathrm{N} 100 \mathrm{P} 50$. High root proportion under low $\mathrm{P}$ conditions has also been reported in previous studies and has shown that $P$ deficiency enhances fine root growth for efficient P absorption (Lynch 1995, Lynch \& Brown 1998, Gilroy \& Jones 2000). In our study, seedlings subjected to the Po treatments may have been experienced a $P$ deficiency. Under high $\mathrm{P}$ conditions, fine root proportion was decreased by $\mathrm{N}$ loading. On the other hand, under low $\mathrm{P}$ conditions, the fine root proportion increased at $\mathrm{N} 50$, though decreased at N100. Therefore, under high $\mathrm{N}$ and $\mathrm{P}$ conditions fine root proportion was decreased. At low $\mathrm{P}$ conditions, $\mathrm{N}$ loading may only have increasing effects up to a certain extent, while an excess of $\mathrm{N}$ loading may have decreased fine root proportion in $\mathrm{F}_{1}$ seedlings.

Needle: fine root biomass ratio was significantly higher under $\mathrm{N}$ loading at P50 treatments, indicating that more investments were made to the aboveground growth. This result was in agreement with previous studies where sufficient availability of water and nutrients result in smaller amounts of fine roots and a smaller percentage of assimilates is transported to roots (Erisman et al. 1998). This phenomenon could also decrease the seedling's tolerance to other stress, such as drought, since roots have the vital role of absorbing not only nutrients but also water (Hodge et al. 2009). At Po treatments, $\mathrm{N}$ did not increase needle: fine root biomass ratio, so it can be speculated that investments were made to fine roots as well as needle production.

The core sampling method may not be fully suitable to accurately evaluate fine roots, as the amount of soil sampled was relatively small compared to the total root biomass ( $1 \%$ of the total pot volume). To accurately evaluate fine root growth using soil core samples, more samplings are needed and more soil volume should be explored, though this could damage the root system and cause a decline in overall seedling growth. Using the in-growth method in parallel to core samples, may have increased the accuracy of fine root evaluation without harming the seedling. Evaluation of fine roots is strongly altered by the methodology (Nadelhoffer 2000), therefore more improvements of fine root measurement methodologies and techniques, such as a non-destructive Mini-rhizotron (MR-fine root observation tubes) method (Wang et al. 2016) could increase the accuracy of estimations.

\section{Conclusion}

$\mathrm{N}$ loading had different effects on aboveand below- ground growth of hybrid larch $\mathrm{F}_{1}$ seedlings. Although, aboveground growth was increased by $\mathrm{N}$ loading under both low and high $\mathrm{P}$ conditions, belowground growth was suppressed. This could affect seedlings' tolerance or susceptibility to other stress, such as drought, since roots have the vital role of water absorption. Root growth of $F_{1}$ could be altered by increasing $\mathrm{N}$ deposition under low $\mathrm{P}$ soil conditions. Furthermore, high $\mathrm{N}$ loading at low $\mathrm{P}$ conditions altered litter quality. This could indirectly accelerate the input of $\mathrm{N}$ to soils. To efficiently use larch $F_{1}$ as an afforestation species, considerations should be taken on the location of plantation site, related to imbalances in $\mathrm{N}$ and $\mathrm{P}$ conditions, especially high $\mathrm{N}$ loading at $\mathrm{P}$ deficient soils.

\section{Acknowledgements}

We thank Dr. Ivano Brunner of WSL of Switzerland for helpful discussion and comments on the manuscript. We are grateful to Dr. Cong Shi, Mr. Testuto Sugai and Dr. Eugenios Agathokleous of Hokkaido University for constructive discussion. Gratitude in also given to Dr. Toshiyuki Hirata and Dr. Yoshitaka Uchida of Hokkaido University for the use of the NC Analyzer. We thank Dr. Toshihiro Watanabe of Hokkaido University for the use the ICP Analyzer and Dr. Tatsuro Nakaji of Hokkaido University for use of WinRHIZO TRON software. This research was in part by Grant-in-aid of basic research, type B (to TK: No.26292075) of Japan Society of Promotion of Science.

\section{References}

Abaimov AP, Zyryanova O, Prokushkin SG (2002). Long-term investigations of larch forests in cryolithic zone of Siberia: brief history, recent results and possible changes under global warming. Eurasian Journal of Forest Research 5: 95-106.

Aber JD, Nadelhoffer KJ, Steudler P, Melillo JM (1989). Nitrogen saturation in northern forest ecosystems. BioScience 39: 378-386. - doi: 10.2307/1311067

Aber JD, Goodale CL, Ollinger SV, Smith $M-L$, Magill AH, Martin ME, Hallett RA, Stoddard JL (2003). Is nitrogen deposition altering the nitrogen status of northeastern forests? BioScience 53: 375-389. - doi: 10.1641/0006-3568 (2003)053[0375:INDATN]2.0.CO;2

Braun S, Thomas VFD, Quiring R, Flückiger W (2010). Does nitrogen deposition increase forest production? The role of phosphorus. Environmental Pollution 158: 2043-2052. - doi: 10.1016/j.envpol.2009.11.030

Burton AJ, Pregitzer KS, Hendrick RL (2000). Relationships between fine root dynamics and nitrogen availability in Michigan northern hardwood forests. Oecologia 125: 389-399. - doi: 10.1007/s004420000455

Chapin FS, Kedrowski RA (1983). Seasonal changes in nitrogen and phosphorus fractions and autumn retranslocation in evergreen and deciduous taiga trees. Ecology 64: 376-391. doi: $10.2307 / 1937083$

Dong-Gyu K, Shi C, Watanabe M, Kita K, Satoh F, Koike T (2015). Growth of Japanese and hybrid larch seedlings grown under free-air $\mathrm{O}_{3}$ fumigationâan initial assessment of the effects of adequate and excessive nitrogen. Journal of Agricultural Meteorology 71: 239-244. - doi: 10.2480/ agrmet.D-14-00029 
Elser JJ, Fagan WF, Kerkhoff AJ, Swenson NG, Enquist BJ (2010). Biological stoichiometry of plant production: metabolism, scaling and ecological response to global change. New Phytologist 186: 593-608. - doi: 10.1111/j.1469-8137.20 10.03214.x

Erisman JW, Draaijers GPJ, Steingröver E, Dijk H, Boxman A, De Vries W (1998). Assessment of the exposure and loads of acidifying and eutrophying pollutants and ozone, as well as their harmful influence on the vitality of the trees and the speulder forest ecosystem as a whole. Water, Air, and Soil Pollution 105: 539-571. - doi: 10.1023/A:1004961610700

Galloway JN, Aber JD, Erisman JW, Seitzinger SP, Howarth RW, Cowling EB, Cosby BJ (2003). The nitrogen cascade. American Institute of Biological Sciences 53: 341-356. - doi: 10.1641/0006-35 68(2003)053[0341:TNC]2.0.CO;2

Galloway JN, Dentener FJ, Capone DG, Boyer EW, Howarth RW, Seitzinger SP, Asner GP, Cleveland CC, Green PA, Holland EA, Karl DM, Michaels AF, Porter JH, Townsend AR, Vörösmarty CJ (2004). Nitrogen cycles: past, present, and future. Biogeochemistry 70: 153-226. - doi: 10.1007/s10533-004-0370-0

Galloway JN, Townsend AR, Erisman JW, Bekunda M, Cai Z, Freney JR, Martinelli LA, Seitzinger SP, Sutton MA (2008). Transformation of the nitrogen cycle: Recent trends, questions, and potential solutions. Science 320: 889-892. doi: $10.1126 /$ science. 1136674

Gilroy S, Jones DL (2000). Through form to function: root hair development and nutrient uptake. Trends in Plant Science 5: 56-60. - doi: 10.1016/S1360-1385(99)01551-4

Gower ST, Richards JH (1990). Larches: deciduous conifers in an evergreen world. BioScience 40: 818-826. - doi: 10.2307/1311484

Güsewell S (2004). N: P ratios in terrestrial plants: variation and functional significance. New Phytologist 164: 243-266. - doi: 10.1111/j.14 69-8137.2004.01192.x

Hodge A, Berta G, Doussan C, Merchan F, Crespi $M$ (2009). Plant root growth, architecture and function. Plant and Soil 321: 153-187. - doi: 10.1007/s11104-009-9929-9

Kaneyasu N, Yamamoto S, Sato K, Takami A, Hayashi M, Hara K, Kawamoto K, Okuda T, Hatakeyama S (2014). Impact of long-range transport of aerosols on the PM2.5 composition at a major metropolitan area in the northern Kyushu area of Japan. Atmospheric Environment 97: 416-425. - doi: 10.1016/j.atmosenv. 2014.01.029

Kita K, Fujimoto T, Uchiyama K, Kuromaru M, Akutsu H (2009). Estimated amount of carbon accumulation of hybrid larch in three 31-yearold progeny test plantations. Journal of Wood Science 55: 425-434. - doi: 10.1007/s10086-0091064-y

Koike T, Kuromaru M, Qu LY, Choi D, Takagi K, Masyagina OV, Wang WJ, Sasa K (2004). Process of larch plantation in northern Japan and development of hybrid larch $\left(F_{1}\right)$ for overcoming biological stresses. In: Proceedings of the "International Congress on Forest Bio-Resources”. Khabarovsk (Russia) 21-24 Sept 2004. Forest Research Institute of Far East, Khabarovsk, Russia, pp. 57-63.

Koike T, Yazaki K, Funada R, Maruyama Y, Mori
S, Sasa K (2000). Forest heath and vitality in northern Japan - A case study on larch plantation. Research Note of Faculty of Forestry, The University of Joensuu, vol. 92, pp. 49-6o.

Li J, Guo Q, Zhang J, Korpelainen H, Li C (2016). Effects of nitrogen and phosphorus supply on growth and physiological traits of two Larix species. Environmental and Experimental Botany 130: 206-215. - doi: 10.1016/j.envexpbot.20 16.06 .006

Lynch (1995). Plant architecture and plant productivity. Plant Physiology 109: 7-13. - doi: 10.1104/pp.109.1.7

Lynch JP, Brown KM (1998). Topsoil foraging - an architectural adaption of plants to low phosphorus availability. Plant and Soil 237: 225-237. doi: 10.1023/A:1013324727040

Magill AH, Aber JD, Currie WS, Nadelhoffer KJ, Martin ME, McDowell WH, Melillo JM, Steudler $P$ (2004). Ecosystem response to 15 years of chronic nitrogen additions at the Harvard Forest LTER, Massachusetts, USA. Forest Ecology and Management 196: 7-28. - doi: 10.1016/j.for eco.2004.03.033

Mao Q (2013). Ecophysiological study on the growth responses of larch species to changing environments - Effects of elevated $\mathrm{CO}_{2}, \mathrm{O}_{3}$, and high nitrogen loading. PhD thesis, Graduate School of Agriculture, Hokkaido University, Sapporo, Hokkaido, Japan, pp. 118.

Mao QZ, Watanabe M, Makoto K, Kita K, Koike T (2014). High nitrogen deposition may enhance growth of a new hybrid larch $F_{1}$ growing at two phosphorus levels. Landscape and Ecological Engineering 10: 1-8. - doi: 10.1007/s11355-012-02 07-2

Matyssek R, Schulze ED (1987). Heterosis in hybrid larch (Larix decidua $\times$ leptolepis). Trees 1 : 225-231. - doi: 10.1007/BF01816820

Matyssek R, Wieser G, Calfapietra C, De Vries W, Dizengremel $P$, Ernst $D$, Jolivet $Y$, Mikkelsen TN, Mohren GMJ, Le Thiec D, Tuovinen JP, Weatherall A, Paoletti E (2012). Forests under climate change and air pollution: gaps in understanding and future directions for research. Environmental Pollution 160: 57-65. - doi: 10.10 16/j.envpol.2011.07.007

Miyaki $Y$ (1990). Superior characters of the $F_{1}$ hybrid Larix gmelinii $\times$ L. kaempferi and the growth gain in full-sib family selection. Forest Tree Breeding 33: 7-12.

Miyaura T, Hozumi K (1988). Measurement of litterfall in a Japanese Larch (Larix leptolepis Gordon) plantation by the cloth-trap method. Journal of the Japanese Forestry Society 70: 11-19. doi: 10.11519/jjfs1953.70.1_11

Nadelhoffer KJ (2000). The potential effects of nitrogen deposition on fine-root production in forest ecosystems. New Phytologist 147: 131139. - doi: 10.1046/j.1469-8137.2000.00677.x

Nakaji T, Takenaga S, Kuroha M, Izuta T (2001). Photosynthetic response of Pinus densiflora seedlings to high nitrogen load. Enviromental Science 9: 296-282.

Ostonen I, Püttsepp U, Biel C, Alberton O, Bakker MR, Lõhmus K, Majdi H, Metcalfe D, Olsthoorn AFM, Pronk A, Vanguelova E, Weih $M$, Brunner I (2007). Specific root length as an indicator of environmental change. Plant Biosystems 141: 426-442. - doi: 10.1080/112635007 01626069
Peñuelas J, Poulter B, Sardans J, Ciais P, Van Der Velde M, Bopp L, Boucher O, Godderis Y, Hinsinger $P$, Llusia J, Nardin E, Vicca S, Obersteiner M, Janssens IA (2013). Human-induced nitrogen-phosphorus imbalances alter natural and managed ecosystems across the globe. Nature Communications 4: 2934. - doi: 10.1038/ncomms 3934

Qu L, Quoreshi AM, Koike T (2003). Root growth characteristics, biomass and nutrient dynamics of seedlings of two larch species raised under different fertilization regimes. Plant and Soil 255: 293-302. - doi: 10.1007/978-94-017-2923-9 28

Qu L (2016). Ecophysiological study on the natural regeneration of the two larch species with special references to soil environment in larch forests. Eurasian Journal of Forest Research 19 (1): 1-51.

Reich PB, Oleksyn J (2004). Global patterns of plant leaf $\mathrm{N}$ and $\mathrm{P}$ in relation to temperature and latitude. Proceedings of the National Academy of Sciences USA 101: 11001-11006. - doi: 10.1073/pnas.0403588101

Ryan MG, Hubbard RM, Pongracic S, Raison RJ, Murtrie REMC (1996). Foliage, fine root, woody-tissue and stand respiration in Pinus radiata in relation to nitrogen status. Tree Physiology 16: 333-343. - doi: 10.1093/treephys/16.3. 333

Ryu K, Watanabe M, Shibata H, Takagi K, Nomura M, Koike T (2009). Ecophysiological responses of the larch species in northern Japan to environmental changes as a basis for afforestation. Landscape and Ecological Engineering 5: 99-106. - doi: 10.1007/s11355-0090063-x

Satoh T (1995). Fundamental studies on the root growth of trees in Hokkaido. Bulletin of the Hokkaido Forestry Research Institute 31: 1-54.

Szmidt AE, Aldén T, Hällgren JE (1987). Paternal inheritance of chloroplast DNA in Larix. Plant Molecular Biology 9: 59-64. - doi: 10.1007/BFoo017987

Takahashi T, Shoji S (2002). Distribution and classification of volcanic ash soils. Global Environmental Research 6: 83-97. [online] URL: http://www.researchgate.net/publication/2288 52848

Tingey DT, Phillips DL, Johnson MG (2000). Elevated $\mathrm{CO}_{2}$ and conifer roots: effects on growth, life span and turnover. New Phytologist 147: 87103. - doi: 10.1046/j.1469-8137.2000.00684.x

Uddling J, Karlsson PE, Glorvigen A, Sellden G (2006). Ozone impairs autumnal resorption of nitrogen from birch (Betula pendula) leaves, causing an increase in whole-tree nitrogen loss through litter fall. Tree Physiology 26: 113-120. doi: 10.1093/treephys/26.1.113

Van Diepen LTA, Frey SD, Sthultz CM, Morrison EW, Minocha R, Pringle A (2015). Changes in litter quality caused by simulated nitrogen deposition reinforce the $\mathrm{N}$-induced suppression of litter decay. Ecosphere 6: 1-16. - doi: 10.1890/ES 15-00262.1

Vitousek PM, Hättenschwiler S, Olander L, Allison S (2002). Nitrogen and nature. AMBIO 31: 97-101. - doi: 10.1579/0044-7447-31.2.97 Vitousek PM, Porder S, Houlton BZ, Chadwick OA (2010). Terrestrial phosphorus limitation: mechanisms, implications, and nitrogen-phos- 
phorus interactions. Ecological Applications 20: 5-15. - doi: 10.1890/08-0127.1

Wang X, Fujita S, Nakaji T, Watanabe M, Satoh F, Koike $T$ (2016). Fine root turnover of Japanese white birch (Betula platyphylla var. japonica) grown under elevated $\mathrm{CO}_{2}$ in northern Japan. Trees 30: 363-374. - doi: 10.1007/s00468-0151282-4

Wang X, Agathokleous E, Qu L, Fujita S, Watanabe M, Tamai Y, Mao Q, Koyama A, Koike T (2017). Effects of simulated nitrogen deposition on ectomycorrhizae community structure in hybrid larch and its parents grown in volcanic ash soil: the role of phosphorous. Science of The Total Envirornment [in press] - doi: 10.1016/ j.scitotenv.2017.08.283

Watanabe M, Watanabe Y, Kitaoka S, Utsugi H, Kita K, Koike T (2011). Growth and photosynthetic traits of hybrid larch $\mathrm{F}_{1}$ (Larix gmelinii var. japonica $\times$ L. kaempferi) under elevated $\mathrm{CO}_{2}$ concentration with low nutrient availability. Tree Physiology 31: 965-975. - doi: 10.1093/tree phys/tpro59

Wei H, Xu C, Ma L, Wang W, Duan J, Jiang L (2014). Short-term nitrogen (N)-retranslocation within Larix olgensis seedlings is driven to increase by $\mathrm{N}$-deposition: evidence from a simulated ${ }^{15} \mathrm{~N}$ experiment in northeast China. International Journal of Agriculture and Biology 16: 1031-1040. [online] URL: http://www.research gate.net/publication/274899961 